\title{
CONDITIONS OF THE FLUID IN THE RHRS PIPE LINE AFTER THE LOSS AND RESTART OF THE RHRS PUMP
}

\author{
Dr. Ching Guey/FP\&L \\ 700 University B/vd \\ Juno Beach, FL 33408 \\ Phone: 561694 3137, Pager: 5617223860 \\ e-mail: ching_guey@fpl.com
}

\author{
GPM - Gallons per Minute \\ MOV - Motor Operated Valve \\ PWR - Pressurized Water Reactor \\ RCS - Reactor Coolant System \\ RHRS - Residual Heat Removal System \\ SDC - Shutdown Cooling
}

\section{ABSTRACT}

Due to a recent event at pressurized water reactor (PWR), the impact of a loss of shutdown cooling during reduced RCS inventory conditions was evaluated. The evaluation for the loss of RHRS assumed loss of shutdown cooling initially and then the RHRS pumps were restored. This analysis is based upon a decay heat rate corresponding to 2.66 days following reactor shutdown with an initial liquid level at the elevation of the reactor flange. When the RHRS pump was restored, the calculation revealed that a void fraction of $10-50 \%$ could exist in the hot leg pipe where the RHRS pumps take suction.

The study presented in this paper was conducted to determine the maximum voids permissible in the hot leg piping and still ensure that the water entering the RHRS pump did not have steam voids. RELAP5 was used to perform this evaluation. RELAP5/M3.3 is a computer code used for the thermalhydraulic analysis of transients and small-break accidents and transients in light-water nuclear power plants. It uses a onedimensional, two-fluid model, consisting of steam and water, with the possibility of the vapor phase containing a noncondensable component. A model of the piping was developed and the conditions presented above were analyzed and the fluid conditions were reviewed.

\author{
Joseph S. Miller/EDA, Inc. \\ 2015 Woodford $R d$ \\ Vienna, VA 22182 \\ Phone: 703 597-2459, Fax: 7033564149 \\ e-mail: JoeMiller@edasolutions.com
}

The results of the RELAP5 analyses indicated that for voids 30 $\%$ or less in the hot leg, the RHRS pump would have adequate suction flow to remain in a stable operational condition.

\section{INTRODUCTION}

Due to a recent outage event at a PWR, a loss of shutdown cooling for 8 minutes occurred during reduced RCS inventory conditions. The head was still on the vessel and water level was at the flange, or approximately $7 \mathrm{ft}$ from Mid-loop of the hot leg. A calculation was performed to evaluate the system response. The calculation showed the possibility of voids in the hot leg piping where the RHRS pump takes suction for shutdown cooling. To determine the safety significance of the event, a concern was raised that the RHRS pumps may not operate with voids in the hot leg piping. To provide evidence that the RHRS pumps will operate with some voiding in the hot leg piping, a RELAP5 model of the RHR piping was constructed and used to perform simulations of hot leg voiding scenarios.

\section{DISCUSSION}

A RELAP5/M3.3 model was constructed to simulate the fluid in the RHRS line from the Hot Leg to the RHRS pump. RELAP5/M3.3 (Ref. 1) is a computer code used for the thermal-hydraulic analysis of transients and small-break accidents and transients in light-water nuclear power plants. RELAP5 uses a one-dimensional, two-fluid model, consisting of steam and water, with the possibility of the vapor phase containing a non-condensable component. The RELAP5 program has been used to solve similar problems to the RHRS flow problem (Refs. 2 \& 3) and has been validated for calculating fluid flow conditions and resulting forcing functions (Ref. 4). 
The RELAP5 model was constructed for the RHRS system and is shown in Figure 1. The model begins from the hot leg (RELAP5 component 104), which is a 30 -inch pipe leaving the reactor vessel. The 14-inch Residual Heat Removal (RHR) connects to the hot leg through junction 401 and traverses to RHRS pump (RELAP5 Component 201) as shown in the diagram in Figure 1.

The model consists of two pumps, i.e., RHRS pumps A and B. For these simulations, pump B (RELAP5 Component 202) was not started. The pumps rated head is 210 feet at a rated flow of $3500 \mathrm{gpm}$. Two motor operated valves (MOVs), were also modeled in series. Loss coefficients and sizes were taken from References 5, 6 \& 7. At time equal zero, the RHRS 14" piping is full of $120^{\circ} \mathrm{F}$ water. The 14 " pipe running from the Hot Leg to pump $\mathrm{A}$ is about 190 feet in length.

\section{RESULTS}

Four cases were analyzed with RELAP5. The first case simulated saturated conditions at 55 psia in the hot leg pipe with the pump A running at a rated flow of 3500 gpm at rated density. The second case was to simulate slightly less than $10 \%$ voids in the Hot Leg piping at 55 psia. The third case was to simulate $30 \%$ voids in the Hot Leg piping at 55 psia and the fourth case was to simulate greater than $40 \%$ in the Hot Leg piping at 55 psia.

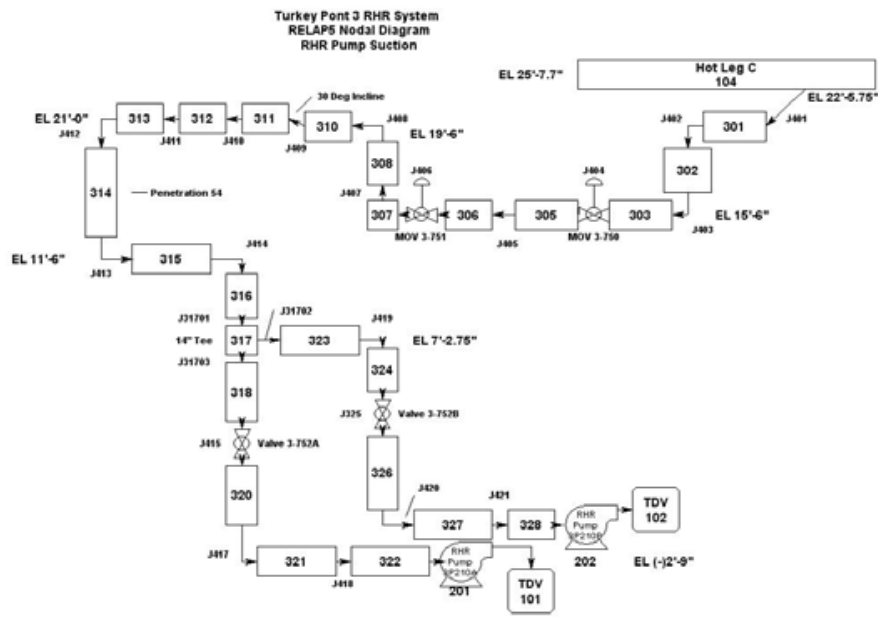

Figure 1 RELAP5 Nodal Diagram of RHRS System

Figure 2 shows the pressure distribution in the RHRS piping for the saturated liquid at 55-psia case. Figure 2 shows that the pressure in the piping leading to the pumps is about 64 psia whereas the pressure at the 14" pipe inlet from the hot leg is about 54 psia. The elevation head change and pressure drops from form losses cause the pressure differences from the Hot Leg to the pump inlet.

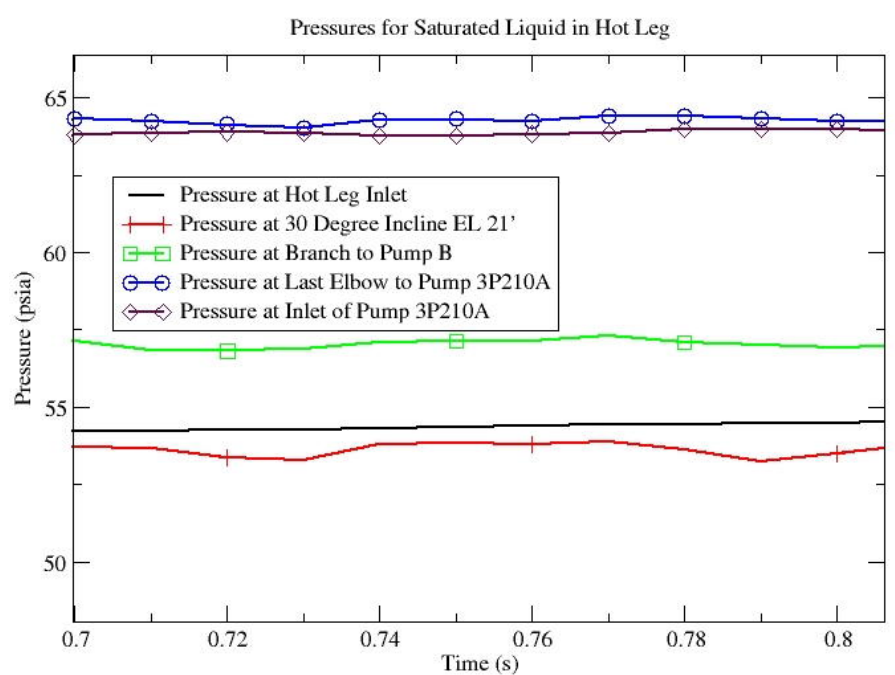

Figure 2 Case 1 Pressures for Saturated Liquid in Hot Leg

Figure 3 shows the densities in the RHRS piping for the saturated liquid case after the cool water $\left(120^{\circ} \mathrm{F}\right)$ has been flushed through the pump. The density in the hot leg piping (i.e., RELAP5 Component 104) is approximately $57 \mathrm{lbm} / \mathrm{ft}^{3}$. The density in the 14" RHRS inlet piping (RELAP5 Component 301) reduces due to the pressure drop from the hot leg to the 14" pipe. The density reduces further as the fluid traverses along the horizontal piping and up the $30^{\circ}$ incline at Elevation 21 feet. Once the fluid flows down into the lower elevation of the pumps (RELAP5 Components 320 and 322), the density increases above the saturated density of the hot leg (RELAP5 Component 104).

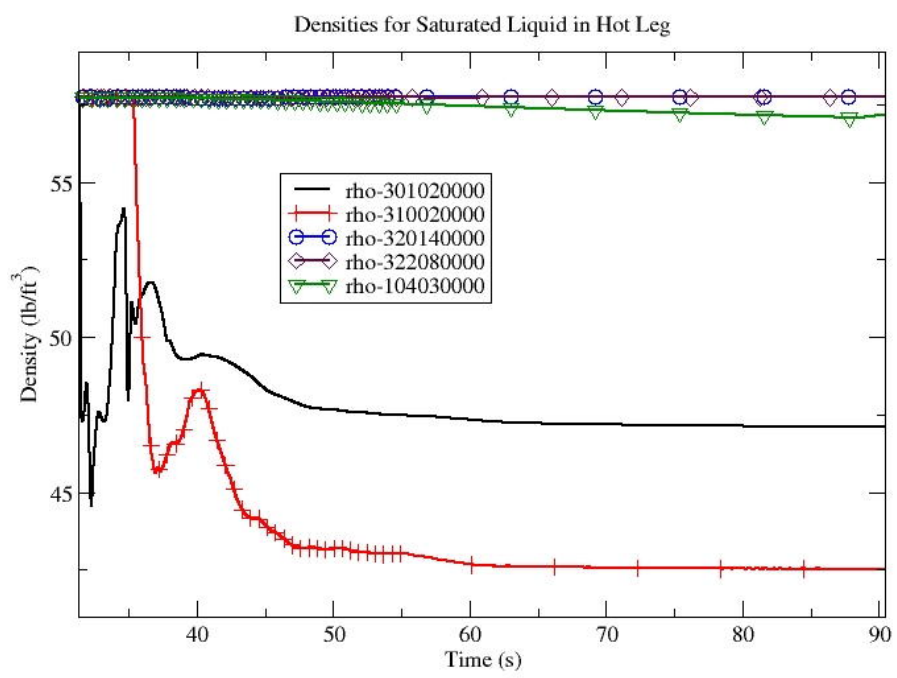


Figure 3 Densities for Saturated Liquid in Hot Leg

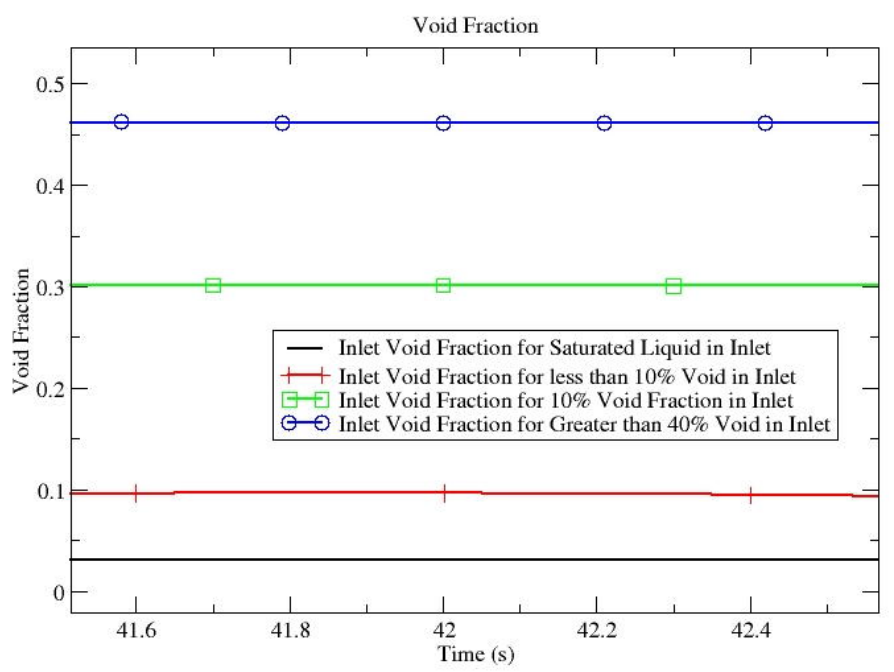

Figure 4 Voids in the 14" RHRS Inlet for the 4 Cases Simulated

Figure 4 shows the voids in the 14" RHRS pipe inlet for the 4 cases. Case 1 assumes saturated liquid in the hot leg, Case 2 assumes slightly less than $10 \%$ voids in the hot leg, Case 3 assumes $30 \%$ voids in the hot leg and Case 4 assumes greater than $40 \%$ voids in the hot leg.

Figure 5 shows the density at the RHRS pump inlet for each of the cases simulated. For Cases 1, 2 and 3 (i.e., saturated liquid in the hot leg, less than $10 \%$ voids in the hot let and $30 \%$ voids in the hot leg, respectively), the density at the RHRS pump inlet was calculated as $58 \mathrm{lbm} / \mathrm{ft}^{3}$. For Case 4, the greater than $40 \%$ voids in the hot leg case, the density was calculated to be $.25 \mathrm{lbm} / \mathrm{ft}^{3}$ and the pump failed to adequately pump fluid.

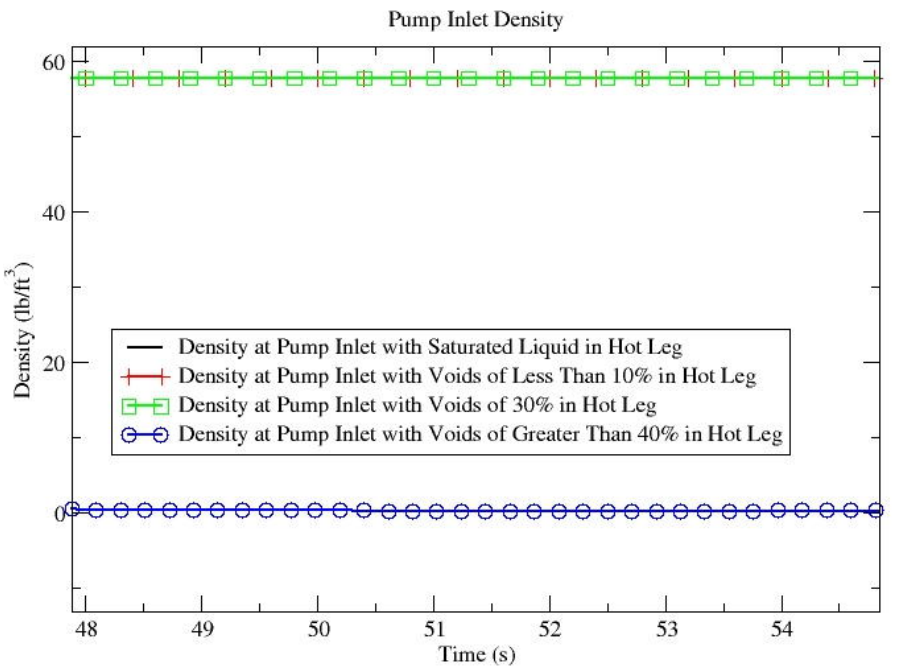

Figure 5 Density in the 13" RHRS Pump Inlet for the 4 Cases Simulated

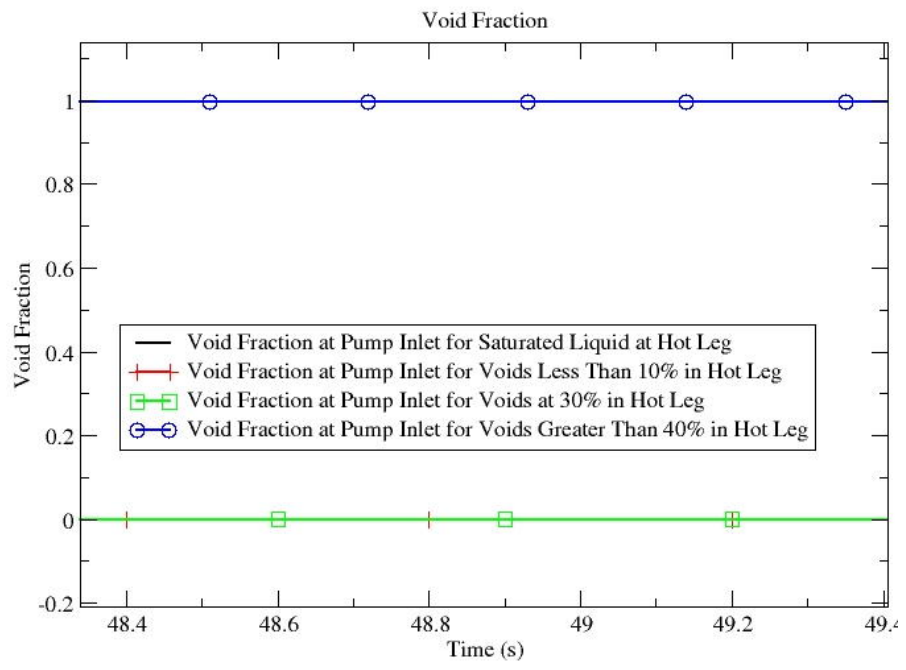

Figure 6 Voids in the 14” RHRS Pump Inlet for the 4 Cases Simulated

Figure 6 shows the steam void at the RHRS pump inlet for each of the cases simulated. For Cases 1, 2 and 3 (i.e., saturated liquid in the Hot Leg, less than $10 \%$ voids in hot let and 30\% voids in hot leg, respectively), the void at the RHRS pump inlet was calculated as 0.0 . For Case 4, the greater than $40 \%$ voids in the hot leg case, the void was calculated to be 1.0 and the pump failed to pump fluid.

Table 1 presents the results of the 4 cases simulated. Cases 1,2 and 3 that represented up to $30 \%$ voiding in the hot leg, indicated that no voiding occurred in the pump inlet. Case 4, which represented the simulated case with greater than $40 \%$ voids in the hot leg, showed that the pump inlet would be completely voided with no flow through the pump.

Table 1 Summary of Results for all Cases

\begin{tabular}{|c|c|c|c|c|}
\hline $\begin{array}{l}\text { RELAP5 } \\
\text { Case }\end{array}$ & Description & $\begin{array}{l}\text { RELAP5 } \\
\text { File }\end{array}$ & $\begin{array}{l}\text { Voids in } \\
\text { Hot Leg }\end{array}$ & $\begin{array}{l}\text { Voids at } \\
\text { Pump 3A } \\
\text { Inlet }\end{array}$ \\
\hline 1 & $\begin{array}{l}\text { Saturated } \\
\text { Liquid in Hot } \\
\text { Leg }\end{array}$ & RHRpg.i & None & None \\
\hline 2 & $\begin{array}{l}\text { Less Than } \\
10 \% \text { Voids in } \\
\text { Hot Leg }\end{array}$ & RHRpd.i & $\begin{array}{l}\text { Less } \\
\text { Than } \\
10 \% \\
\text { Voids } \\
\end{array}$ & None \\
\hline 3 & $\begin{array}{l}30 \% \text { Voids in } \\
\text { Hot Leg }\end{array}$ & RHRpe.i & $\begin{array}{l}30 \% \\
\text { Voids }\end{array}$ & None \\
\hline 4 & $\begin{array}{l}\text { Greater Than } \\
40 \% \text { Voids in } \\
\text { Hot Leg }\end{array}$ & RHRpf.i & $\begin{array}{l}\text { Greater } \\
\text { Than } \\
40 \% \\
\text { Voids }\end{array}$ & $\begin{array}{l}100 \% \\
\text { Voiding }\end{array}$ \\
\hline
\end{tabular}




\section{CONCLUSIONS}

Four cases were simulated with RELAP5. Case 1 simulated saturated conditions at 55 psia in the hot leg pipe. Case 2 simulated slightly less than 10 voids in the hot leg piping at 55 psia. Case 3 simulated $30 \%$ voids in the hot leg piping at 55 psia and Case 4 simulated greater than $40 \%$ in the hot leg piping at 55 psia. For all cases, the A pump was running at a rated flow of 3500 gpm at rated density.

The results of the RELAP5 analyses indicated that for voids 30 $\%$ or less in the hot leg, the RHRS pump would have adequate suction density and flow to remain in a stable operational condition.

\section{REFERENCES}

1) NUREG/CR-5535/Rev1, RELAP5/MOD3.3 VOLUMES 1 through 8, Prepared by Information Systems Laboratories, Inc., Idaho Falls, ID for Division of Systems Research, NRC, Washington, DC 20555. December 2001.

2) "Solving Reactor Water Clean-up System Anomalies Using RELAP5MOD3.3”, Joseph S. Miller and Chris Brenan, $11^{\text {th }}$ International Conference on Nuclear Engineering, ICONE11, Tokyo, JAPAN, ICONE11-36149, April 20-23, 2003.

3) "Calculation of Forces on Reactor Containment Fan Cooler Piping”, Joseph S. Miller and Kevin Ramsden, $12^{\text {th }}$ International Conference on Nuclear Engineering, ICONE12, Arlington, Virginia, ICONE12-49214, April 2529, 2004.

4) "Validation of a Thermal Hydraulic Computer Code to Perform Two-Phase Multi-Component Force Calculations for Structural Evaluations”, Joseph S. Miller and Kevin Ramsden, $13^{\text {th }}$ International Conference on Nuclear Engineering, ICONE13, Beijing, China, ICONE13-50297, May 16-21, 2005.

5) I.E. Idel' Chik, "Handbook of Hydraulic Resistance, Coefficients of Local Resistance and of Friction”, AECTR-6630, (1966).

6) "Flow of Fluids Through Valves, Fittings and Pipe", Technical Paper No. 410, CRANE, Twenty Fifth Printing 1991.

7) NAVCO PIPING DATALOG, National Valve and Manufacturing Company, Edition No. 10 (Rev. June 1, 1974) 1966. 